\title{
Ichneumonidae (Hymenoptera) parasitoids of Lepidoptera caterpillars feeding on Croton floribundus Spreng (Euphorbiaceae)
}

\author{
Luciana Bueno dos Reis Fernandes ${ }^{1}$, Manoel Martins Dias Filho², Marcelo Adorna Fernandes² \\ \& Angelica Maria Penteado-Dias ${ }^{2}$
}

\begin{abstract}
${ }^{1}$ Programa de Pós-Graduação em Ecologia e Recursos Naturais, Universidade Federal de São Carlos, Via Washington Luis, km 235 - Caixa Postal 676, 13565 905 São Carlos-SP, Brasil. lucianabrfernandes@yahoo.com.br

${ }^{2}$ Universidade Federal de São Carlos, Departamento de Ecologia e Biologia Evolutiva, Via Washington Luis, km 235 - Caixa Postal 676, $13565-905$ São Carlos-SP, Brasil.manoelmd@ufscar.br; mafernandes@ufscar.br; angelica@ufscar.br
\end{abstract}

\begin{abstract}
Ichneumonidae (Hymenoptera) parasitoids of Lepidoptera caterpillars feeding on Croton floribundus Spreng (Euphorbiaceae). Parasitoids of the family Ichneumonidae (Hymenoptera) were obtained during an inventory of Lepidoptera larvae caught feeding in the wild on Croton floribundus (Euphorbiaceae). The Lepidoptera larvae were collected from host plants along trails inside three preserved forest areas in the Brazilian state of São Paulo. Fifteen different species of Ichneumonidae belonging to five subfamilies (Banchinae, Campopleginae, Cremastinae, Mesochorinae and Metopiinae) were obtained. Seven species of Ichneumonidae were reared from leaf rollers: Meniscomorpha sp. (Banchinae) and Leurus caeruliventris (Cresson) (Metopiinae) from Dichomeris sp. (Gelechiidae); Mesochorus sp.1 (Mesochorinae) [as a parasitoid of Hypomicrogaster sp. (Braconidae, Microgastrinae)], Campoplex sp. (Campopleginae) and Leurus sp. from Olethreutinae sp. (Tortricidae); Sphelodon annulicornis Morley (Banchinae) and Eutanygaster brevipennis Cameron (Cremastinae) were also reared from two unidentified species of Gelechiidae. The other eight species were reared from the larvae of exposed feeders: Diradops sp. (Banchinae) from Miselia albipuncta Hampson (Noctuidae), Casinaria sp. (Campopleginae) from Hymenomima conia Prout (Geometridae), Charops sp. (Campopleginae) from Bagisara paulensis Schaus (Noctuidae) and Oxydia vesulia (Cramer) (Geometridae), two species of Hyposoter Förster (Campopleginae) from Semaeopus sp. (Geometridae) and H. conia, two species of Microcharops Roman (Campopleginae) from B. paulensis and an unidentified species of Limacodidae and Mesochorus sp. 2 [reared from what was probably Aleiodes sp. (Braconidae, Rogadinae)] from an unidentified species of Noctuidae.
\end{abstract}

KEYWORDS. Atlantic Forest; capixingui; cocoon; Neotropical; parasitoid.

RESUMO. Ichneumonidae (Hymenoptera) parasitóides de larvas de Lepidoptera associadas a Croton floribundus Spreng (Euphorbiaceae). Parasitóides da família Ichneumonidae (Hymenoptera) foram obtidos durante um inventário de larvas de Lepidoptera sobre Croton floribundus (Euphorbiaceae). As larvas de Lepidoptera foram coletadas sobre as plantas que ocorrem nas bordas de caminhos em três áreas preservadas de mata do Estado de São Paulo, Brasil. Quinze espécies pertencentes a cinco subfamílias (Banchinae, Campopleginae, Cremastinae, Mesochorinae and Metopiinae) foram registradas. Sete espécies de Ichneumonidae foram obtidas de larvas que elaboram abrigos: Meniscomorpha sp. (Banchinae) e Leurus caeruliventris (Cresson) (Metopiinae) parasitóides de Dichomeris sp. (Gelechiidae); Mesochorus sp.1 (Mesochorinae) [parasitóide de Hypomicrogaster sp. (Braconidae, Microgastrinae)], Campoplex sp. (Campopleginae) e Leurus sp. sobre Olethreutinae sp. (Tortricidae); Sphelodon annulicornis Morley (Banchinae) e Eutanygaster brevipennis Cameron (Cremastinae) parasitóides de duas espécies não identificadas de Gelechiidae. As outras oito espécies foram obtidas de larvas encontradas em situações expostas: Diradops sp. (Banchinae) sobre Miselia albipuncta Hampson (Noctuidae), Casinaria sp. (Campopleginae) sobre Hymenomima conia Prout (Geometridae), Charops sp. (Campopleginae) parasitóide de Bagisara paulensis Schaus (Noctuidae) e Oxydia vesulia (Cramer) (Geometridae), duas espécies de Hyposoter Förster (Campopleginae) sobre Semaeopus sp. (Geometridae) e H. conia, duas espécies de Microcharops Roman (Campopleginae) sobre Bagisara paulensis e Limacodidae sp., e Mesochorus sp. 2 [provavelmente parasitóide de Aleiodes sp. (Braconidae, Rogadinae)] sobre espécie não identificada de Noctuidae.

PALAVRAS-CHAVE. Capixingui; casulo; Mata Atlântica; Neotropical; parasitóide.

There are thousands of species of Ichneumonidae; they are among the main parasitoids of Lepidoptera, although the specific hosts are unknown for most Neotropical species. Biological data are provided by Townes (1969, 1970a, 1970b, 1971), Townes \& Townes (1966, 1978), Gauld (1991, 1997, 2000), Gauld et al. (2002), Hanson \& Gauld $(1995,2006)$ and Yu et al. (2005).

A great deal of research is devoted to the study of natural enemies of lepidopterans of economic interest. However, studies relating parasitoids to their hosts and the plants on which they feed in the wild are rare for the Neotropical region. In Brazil, biological data for Ichneumonidae reared from
Lepidoptera larvae are provided by Braga et al. (2001) and Marconato et al. (2008), for Geometridae larvae feeding on Piper spp. (Piperaceae) in a semideciduous forest at Canchim Farm, and for Geometridae on Erythroxylum microphyllum St.-Hilaire (Eythroxylaceae) in a cerrado area at São Carlos, São Paulo, respectively.

The Ichneumonidae obtained for this study were part of a biodiversity inventory of Lepidoptera caterpillars and their parasitoids found feeding on Croton floribundus Spreng (Euphorbiaceae), a native plant of Brazil. C. floribundus is a pioneer species, characteristic of secondary semideciduous forests, widely used in reforestation programs, and was chosen 
to be common and abundant on the forest edges and to allow caterpillar collections. Occasional surveys prior to that of the present work also indicated that this plant hosts a wide range of Lepidoptera species and Hymenoptera parasitoids.

The aim of this paper is to investigate biological aspects and the biodiversity of Hymenoptera parasitoids, especially those from the Ichneumonidae family, and relate them to their hosts.

\section{MATERIAL AND METHODS}

The specimens were collected from three preserved forest areas in the state of São Paulo (Table I) where Croton floribundus is frequently found growing as shrubs in light shade along trails, or as tall trees with fully insolated crowns up to ten meters in height at the edge of the forest.

In surveys made at São Carlos during 1995 to 1997, only Geometridae larvae were systematically collected, although Lepidoptera larvae from other families were occasionally reared; from 1999 to 2001, all caterpillars found on $C$. floribundus were collected, whereas lepidopteran leaf miners were not included.

The caterpillars were collected from host shrubs in the field using direct search, an entomological umbrella or a $3.3-\mathrm{m}^{2}$ white cloth on the ground under the taller plants, which were then shaken with a wooden stick. The caterpillars were reared individually in transparent plastic cages (250 or $500 \mathrm{ml}$ ) with a piece of paper on the bottom (changed daily). The cages were maintained at room temperature, and the caterpillars fed daily with fresh, moist leaves of $C$. floribundus. When parasitoids emerged from the caterpillars, they were left in the cages on a piece of paper, which was moistened daily until the adult emerged.

The remains of the host larvae were preserved in Dietrich's solution for two days and then in 70\% alcohol; the adult parasitoids were pinned with their respective cocoons. The taxonomic identification of Ichneumonidae followed Townes \& Townes (1966), Gupta (1987), Hanson \& Gauld (1995), Gauld (2000) and Gauld et al. (2002). The specimens were deposited in the "Coleção Entomológica do Departamento de Ecologia e Biologia Evolutiva (DCBU)” of the Federal University of São Carlos (UFSCar). The images of Ichneumonidae (adults and cocoons) were obtained with a CCD camera using a stereomicroscope.

\section{RESULTS AND DISCUSSION}

A total of 2.490 caterpillars of 65 Lepidoptera species were collected on Croton floribundus and reared in captivity; twenty seven larvae were parasitized by Ichneumonidae; from three of them the wasps failed to develop. Fifteen different koinobiont endoparasitoid species of Ichneumonidae were reared from eleven Lepidoptera species (Table II).

The specimen of Dichomeris sp. (Gelechiidae) and that of the Olethreutinae subfamily (Tortricidae) were not identified; they are probably new species (Vitor C. Becker, personal communication). Their caterpillars were collected from shelters made with rolled or tied parts of leaves. The caterpillars of Geometridae, Noctuidae and Limacodidae are exposed feeders and are usually found on the underside of leaves.

The caterpillars which were parasitized by Ichneumonidae were collected from January to September and in December. The absence of Ichneumonidae during October and November coincides with the lowest density of host caterpillars and with the season when almost all the leaves of Croton floribundus become rust-colored and fall from the trees and shrubs.

Banchinae. Three species were reared from five caterpillars collected in São Carlos. The two species with long ovipositors - Meniscomorpha sp. and Sphelodon annulicornis Morley, 1914 - attacked microlepidopterous concealed hosts, while Diradops sp., which has a short ovipositor, attacked an exposed macrolepidopterous larvae (Noctuidae), confirming Gauld et al. (2002).

The Diradops sp. (Fig. 1) larva was reared from a Miselia albipuncta Hampson, 1911 (Noctuidae, Hadeninae) caterpillar, an exposed feeder, in the final instar stage; it spun a translucid brownish cocoon (12.6 x $3.7 \mathrm{~mm}$; Fig. 2) next to the remains of the host larva; the pupal stage lasted 16 days.

The Meniscomorpha sp. (Figs. 3-4) larvae were reared from Dichomeris sp. (Gelechiidae, Dichomeridinae) caterpillars, which were consumed in the prepupal stage. One specimen (female) left the shelter of the host and constructed a web of ash gray silk on the bottom of the cage, under which it pupated, without the elaboration of a cocoon; two male specimens spun brownish cocoons ( 8 × 2 mm; Fig. 5) inside the host's shelter; the pupal stage lasted 11 days. Gauld et al. (2002) consider Meniscomorpha Schmiedeknecht, 1907 a senior synonym of Eudeleboea López Cristóbal, 1935. Townes \& Townes (1978) cite Dichomeris ligulella Hübner, 1818 as a host of Eudeleboea mirabilis (Cresson, 1870) and Eudeleboea pleuralis (Ashmead, 1890).

The Sphelodon annulicornis (Fig. 6) larva was reared from a non identified Gelechiidae caterpillar, consumed in the prepupal stage. The parasitoid larva then left the shelter of the host and constructed a translucid, elliptical cocoon; the pupal stage lasted 9 days.

Campopleginae. This was the most abundant subfamily, with seven species obtained from fifteen caterpillars. Campoplex sp. was reared from a concealed host and pupated in a soft cocoon inside the host's shelter. Excluding Microcharops longiterebra Gupta, 1987 which pupated inside of a mummified Limacodidae caterpillar, the species reared from exposed feeders spun hard camouflaged cocoons resembling bird faeces, attached to the leaf or suspended by a short thread, to pass the pupal stage.

The Campoplex sp. (Fig. 7) larva was reared from an Olethreutinae (Tortricidae) caterpillar, which was consumed during the prepupal stage; the parasitoid larva then constructed a yellowish, elliptical silk cocoon (7.8 x 2.0 mm; Fig. 8) inside the pupation site prepared by the host; the pupal stage lasted approximately 10 days. Many species of Campoplex Gravenhorst, 1829 are mentioned by Yu et al. (2005) as parasitoids of Olethreutinae larvae.

The Casinaria sp. (Fig. 9) larva was reared from a 


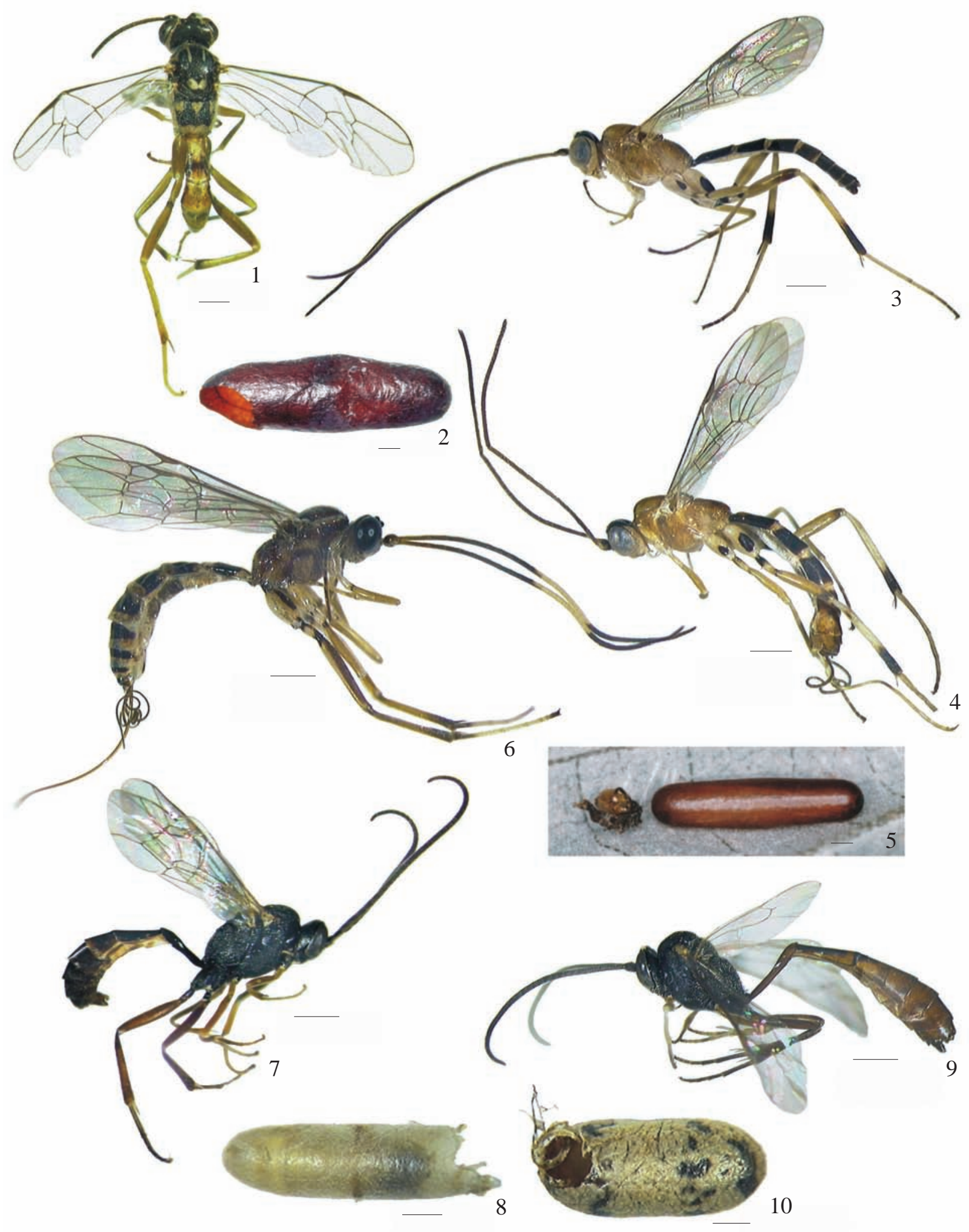

Figs. 1-10. Ichneumonidae. 1-6, Banchinae. 1-2, Diradops sp.; 1, female, habitus; 2, cocoon. 3-5, Meniscomorpha sp.; 3, male, habitus; 4, female, habitus; 5, cocoon beside host remains (Gelechiidae: Dichomeris sp.). 6, Sphelodon annulicornis, female, habitus. 7-10, Campopleginae. 7-8, Campoplex sp.; 7, male, habitus; 8, cocoon. 9-10, Casinaria sp.; 9, female, habitus; 10, cocoon. Scale bar: $1 \mathrm{~mm}$.

Hymenomima conia Prout, 1931 (Geometridae, Ennominae) caterpillar; the prepupal wasp emerged from the penultimate instar caterpillar and spun a very firm, beige silk cocoon with black spots (Fig. 10), attached to the underside of the leaf near the remains of the host larva. These results confirm data from Jerman \& Gauld (1988). The cocoon of the male measured 
Table I. Sites location in São Paulo State, dates of sampling, number of Lepidoptera caterpillars collected (C) and number of caterpillars parasitized by Ichneumonidae (P).

\begin{tabular}{|c|c|c|c|c|c|c|}
\hline City & Site & Vegetation & Date or Period & Periodicity & $\mathrm{C}$ & $\mathrm{P}$ \\
\hline \multirow[t]{5}{*}{ São Carlos } & Canchim Farm (EMBRAPA/ & Atlantic Forest & July/1995 to June/1996 & Once a month & 71 & 2 \\
\hline & Centro de Pesquisa de Pecuária & (Floresta Estacional & June/1997 & One day* & 14 & 1 \\
\hline & do Sudeste) (elev. 872m) & Semidecidual) & April/1999 to March/2000 & Once a fortnight & 981 & 12 \\
\hline & $21^{\circ} 57 ’ 51.62 ”, S$ & & & & & \\
\hline & $47^{\circ} 50^{\prime} 39.05^{\prime \prime} \mathrm{W}$ & & & & & \\
\hline \multirow[t]{4}{*}{ Matão } & Cambuhy Farm & Atlantic Forest & September/1999 to August/2000 & Once a fortnight & 1346 & 9 \\
\hline & (elev. 575m) & (Floresta Estacional & & & & \\
\hline & 213'ㄹ.66”'S & Semidecidual) & & & & \\
\hline & $48^{\circ} 31^{\prime} 49.58^{\prime \prime} \mathrm{W}$ & & & & & \\
\hline \multirow[t]{3}{*}{ Ubatuba } & $\begin{array}{l}\text { Anchieta Island State Park } \\
\text { (elev. 15m) }\end{array}$ & $\begin{array}{l}\text { Atlantic Forest } \\
\text { (Floresta Ombrófila) }\end{array}$ & March/2001 & Three days* & 78 & 3 \\
\hline & $23^{\circ} 32^{\prime} 32.70^{\prime \prime} \mathrm{S}$ & & & & & \\
\hline & $45^{\circ} 03$ '32.09’'W & & & & & \\
\hline
\end{tabular}

* sporadic / eventual

$6.4 \times 2.9 \mathrm{~mm}$, whereas that of the female was $6.0 \times 3.0 \mathrm{~mm}$. The pupal stage lasted 8 days for the male (August, $\pm 19^{\circ} \mathrm{C}$ ) and 13 days for the female (June, $\pm 18^{\circ} \mathrm{C}$ ).

The Charops sp. (Fig. 11) larvae were reared from two different species of caterpillars; both were consumed halfway through development. The prepupal wasp that emerged from Bagisara paulensis Schaus, 1898 (Noctuidae, Bagisarinae), spun a very firm, black-mottled beige silk cocoon, far from the remains of the host larva; the pupal stage lasted 7 days. The specimen that emerged from Oxydia vesulia (Cramer, 1779) (Geometridae, Ennominae) spun a cocoon (4.5 mm) similar to that described above, but suspended by a short thread (Fig. 12). A third specimen (male) emerged from a similar cocoon $(5.2 \mathrm{~mm})$ found suspended from a $C$. floribundus leaf in the wild during February, but without the remains of the host. Three parasitoid larvae with cocoons resembling those of Charops sp. were raised from fourth instar Fountainea ryphea phidile (Geyer, 1834) and Memphis appias (Hübner, 1825) (Nymphalidae, Charaxinae) caterpillars found in Matão (June, July and September); however the parasitoid wasps failed to develop.

Two species of Hyposoter Förster, 1869 were reared from Geometridae caterpillars found at the São Carlos site. The prepupal larva of Hyposoter sp. 1 (Fig. 13) emerged from a fully grown ( $5^{\text {th }}$ instar) Semaeopus sp. (Sterrhinae) caterpillar; it spun a hard, black-mottled beige silk cocoon (7 mm), under the remains of the host larva (Figs. 14-15); attached to the leaf. The pupal stage lasted 9 days. The prepupal larva of Hyposoter sp. 2 (Fig. 16) emerged from a penultimate instar Hymenomima conia (Ennominae) caterpillar and spun a hard, brownish cocoon $(4.1 \mathrm{~mm}$; Fig. 17) near the remains of the host larva; the pupal stage lasted 12 days.

Two species of Microcharops Roman, 1910 were also found associated with Croton floribundus. The Microcharops longiterebra (Fig. 18) larvae pupated inside the shrunken and mummified remains (9 mm; Fig. 19) of an unidentified species of Limacodidae (sp. 3); the pupal stage lasted 7 days, with the adult wasp emerging through a circular hole at the posterior dorsal end of the caterpillar. The prepupal larva of Microcharops sp. (Fig. 20) emerged from a fully grown larva of Bagisara paulensis (Noctuidae, Bagisarinae) and spun a hard, black-mottled beige silk cocoon $(5.3 \mathrm{~mm})$ attached to the underside of the leaf under the remains of the host larva (Fig. 21); the pupal stage lasted 5 days. According to the key provided by Gupta (1987) this species of Microcharops belongs to the Tibialis Group, somewhat in between $M$. rufoantennata and $M$. peronota.

Cremastinae. Eutanygaster brevipennis Cameron, 1911 (Fig. 22) was reared from an unidentified species of Gelechiidae collected in Ubatuba; the prepupal larva emerged from the prepupal caterpillar and spun a yellowish translucid cocoon (7.5 mm; Fig. 23) next to the remains of the host inside the rolled leaf coated with white silk prepared by the host caterpillar. These results confirm those reported by Hanson \& Gauld (1995, 2006) for the subfamily; the pupal stage lasted 7 days.

Mesochorinae. Two hyperparasitoid species of Mesochorus Gravenhorst, 1829 were reared from Braconidae species collected in São Carlos; both killed their hosts after these had killed the caterpillar primary host and constructed a cocoon, confirming the report of Hanson \& Gauld (1995, 2006).

The Mesochorus sp. 1 wasp (Fig. 24) emerged from a Hypomicrogaster sp. (Braconidae, Microgastrinae) cocoon. Hypomicrogaster sp. are solitary parasitoids and these specimens were reared from eleven caterpillars of Olethreutinae sp. (Tortricidae), Dichomeris sp. (Gelechiidae) and Lygropia unicoloralis (Guenée, 1854) (Pyralidae), all found in São Carlos. The prepupal larva of Hypomicrogaster sp. emerged from the fully grown Olethreutinae sp. caterpillar, and spun a white silk cocoon, with a cone-shaped end and a circular frontal operculate opening (4.9-6.7 mm; Fig. 25) inside the rolled leaf shelter of the host. The hyperparasitoid wasp emerged from the braconid cocoon, through the operculate opening, 20 days after Hypomicrogaster sp. spun its cocoon.

The Mesochorus sp. 2 (Fig. 26) wasp emerged from an unidentified Noctuidae (sp. 3) caterpillar mummified by Rogadinae (Braconidae; probably Aleiodes Wesmael, 1838). The host mummy (5.7 mm; Fig. 27) was glued down to the 

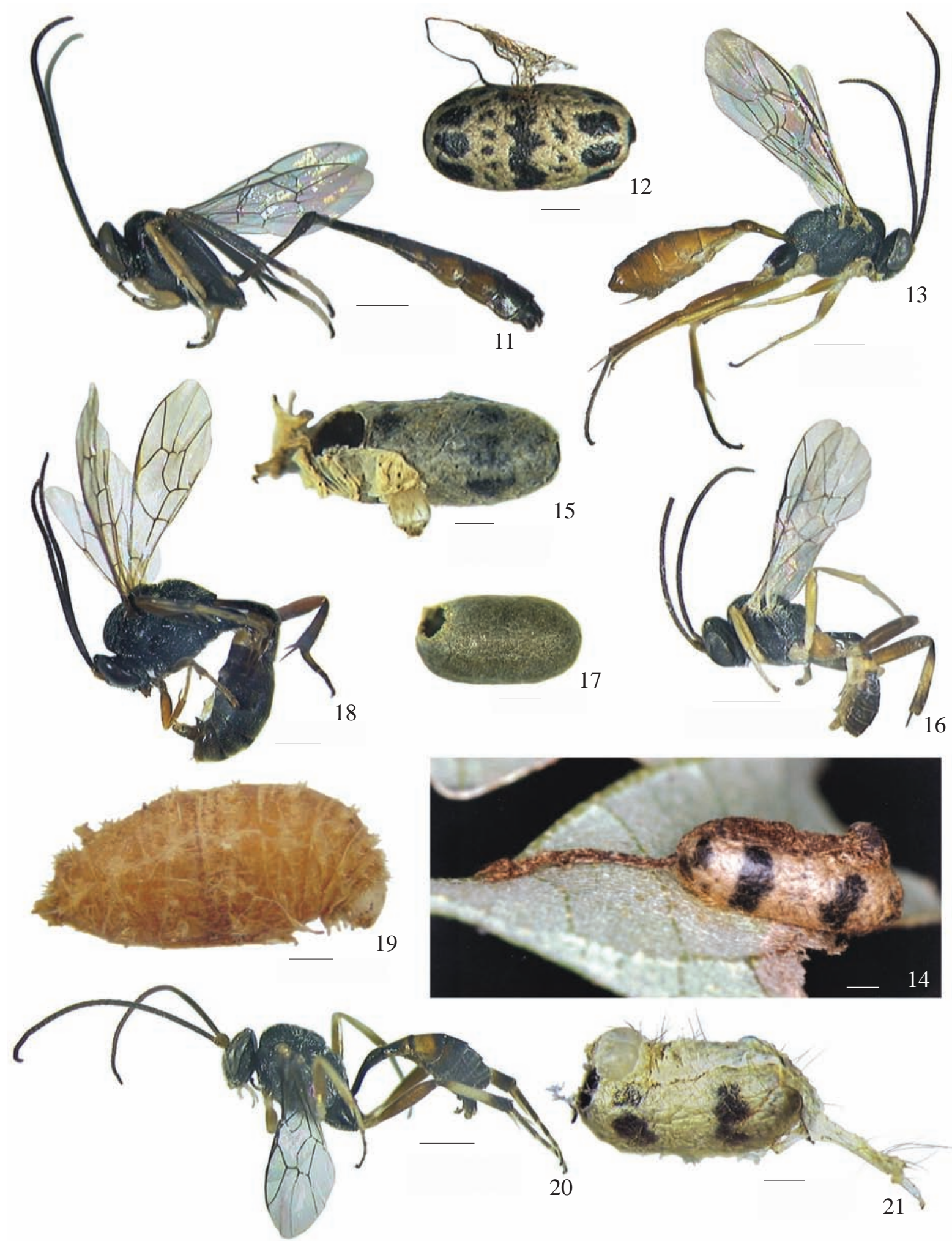

Figs. 11-21. Ichneumonidae: Campopleginae. 11-12, Charops sp.; 11, male, habitus; 12, cocoon. 13-15, Hyposoter sp. 1; 13, female, habitus; 14-15, cocoon under host remains (Geometridae: Semaeopus sp.); 16-17, Hyposoter sp. 2; 16, male, habitus; 17, cocoon. 18-19, Microcharops longiterebra; 18, male, habitus; 19, mummified caterpillar remains (Limacodidae sp. 3). 20-21, Microcharops sp.; 20, male, habitus; 21, cocoon under host remains (Noctuidae: Bagisara paulensis). Scale bar: $1 \mathrm{~mm}$.

leaf by the Rogadinae larva through a hole chewed in the bottom of the host's prothorax, as Aleiodes usually does (Shaw 1997). The Mesochorus sp. 2 wasp emerged through a hole at the posterior end of the mummified caterpillar. Specimens of Aleiodes sp. were also obtained from eight Geometridae caterpillars of four species [Glena sp., Hymenomima amberia 


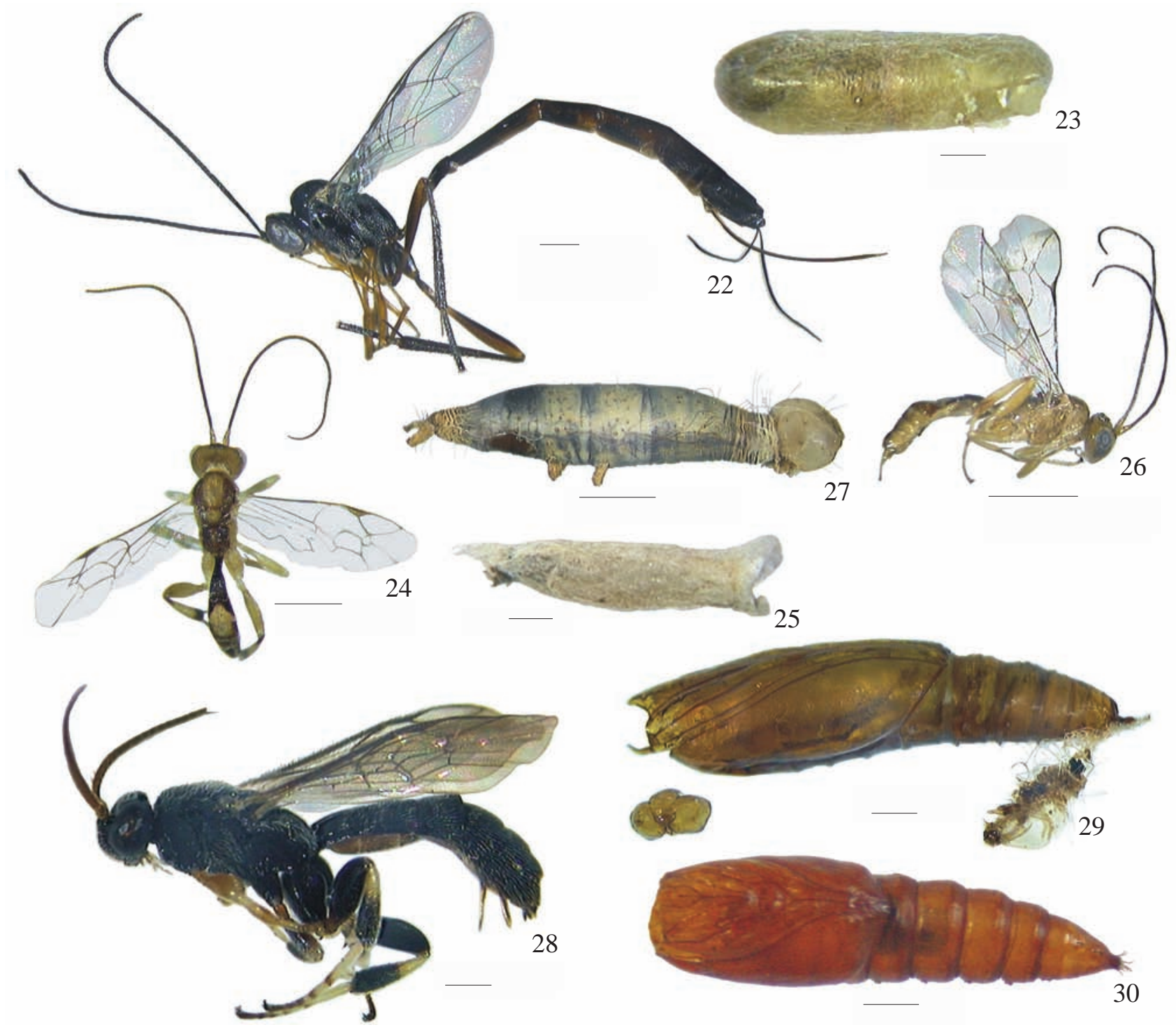

Figs. 22-30. Ichneumonidae. 22-23, Eutanygaster brevipennis (Cremastinae); 22, female, habitus; 23, cocoon. 24-27, Mesochorinae. 24-25, Mesochorus sp. 1; 24, female, habitus; 25, cocoon of Hypomicrogaster acontes (Braconidae). 26-27, Mesochorus sp. 2; 26, female, habitus; 27, Noctuidae caterpillar remains mummified by Rogadinae (Braconidae). 28-30, Leurus spp. (Metopiinae); 28, L. caeruliventris, female, habitus; 29, host pupa and last exuvia of Dichomeris sp. (Gelechiidae); 30, host pupa (Tortricidae: Olethreutinae sp.) of Leurus sp.. Scale bar: $1 \mathrm{~mm}$.

(Schaus, 1901), Melanolophia sp. and Physocleorajunctilinea (Warren, 1901)], found on Croton floribundus at São Carlos and Matão districts.

Metopiinae. Two species of Leurus Townes, 1946 were reared from three microlepidoptera caterpillars sheltered within rolled leaves, confirming the data reported by Gauld et al. (2002) for this subfamily. The adult female wasp of Leurus caeruliventris (Cresson, 1868) (Fig. 28) emerged from the pupae of Dichomeris sp. (Gelechiidae) (Fig. 29) and two adult males of Leurus sp. eclosed from the pupae of Olethreutinae sp. (Tortricidae) (Fig. 30). The hosts were collected when they were still growing larvae. Both species emerged from the host through the pupal head 16 days after host pupation.

All of these genera of Ichneumonidae were found for the first time in association with caterpillars feeding on Croton floribundus and all the non-identified Ichneumonidae species are probably new taxa and are not yet formally described.

There have been no previous reports of Eutanygaster brevipennis occurring in Brazil, nor of Leurus and Sphelodon annulicornis in the state of São Paulo, Brazil. Mesochorus is also being reported for the first time as a hyperparasitoid of Hypomicrogaster sp. (Braconidae, Microgastrinae), reared from an Olethreutinae (Tortricidae) caterpillar; new Lepidoptera host relationships have also been found for Diradops, Casinaria, Charops, Microcharops, Hyposoter, Leurus and Leurus caeruliventris; no hosts were previously known for Sphelodon annulicornis and Eutanygaster brevipennis which were reared from Gelechiidae caterpillars, nor for Microcharops longiterebra, which was reared from a Limacodidae caterpillar. 
Table II. Ichneumonidae reared from Lepidoptera caterpillars feeding on Croton floribundus (Euphorbiaceae) in São Carlos, Matão and Ubatuba (São Paulo State, Brazil). The column "P” represents the percentage number of caterpillars parasitized by its respective parasitoid wasp (Ichneumonidae species).

\begin{tabular}{|c|c|c|c|c|c|c|c|c|c|c|}
\hline \multicolumn{2}{|c|}{ Ichneumonidae } & \multicolumn{2}{|c|}{$\begin{array}{c}\text { Number of } \\
\text { rearings }\end{array}$} & \multicolumn{2}{|c|}{ Occurrence } & \multirow{2}{*}{\multicolumn{2}{|c|}{ Lepidoptera (primary host) }} & \multirow{2}{*}{$\begin{array}{c}\text { Month } \\
\text { of } \\
\text { occurrence }\end{array}$} & \multirow{2}{*}{$\begin{array}{c}\text { Number } \\
\text { of } \\
\text { specimens }\end{array}$} & \multirow{2}{*}{$\begin{array}{c}\mathrm{P} \\
(\%)\end{array}$} \\
\hline & & $\hat{0}$ & q & Site & Month(s) & & & & & \\
\hline \multirow[t]{3}{*}{ Banchinae } & Diradops sp. & 0 & $1 \mathrm{~s}$ & São Carlos & S VIII & Noctuidae & Miselia albipuncta & VII-IX, XI & 10 & 10.0 \\
\hline & Meniscomorpha sp. & 2 & 1 & & I, III-IV & Gelechiidae & Dichomeris sp. & I-X, XII & 45 & 6.7 \\
\hline & Sphelodon annulicornis & 0 & 1 & & VII & Gelechiidae & sp. 1 & VII & $1 * * *$ & - \\
\hline \multirow[t]{8}{*}{ Campopleginae } & Campoplex sp. & 1 & $0 S$ & São Carlos & VII & Tortricidae & Olethreutinae sp. & II-VIII, X & 31 & 3.2 \\
\hline & Casinaria sp. & 1 & 1 & & VI, VIII & Geometridae & Hymenomima conia & I, IV-X & 21 & 9.5 \\
\hline & Charops sp. & 1 & 0 & Matão & XII & Noctuidae & Bagisara paulensis & I-III, XII & 49 & 2.0 \\
\hline & & 0 & 1 & & VI & Geometridae & Oxydia vesulia & II-VI & 7 & 14.3 \\
\hline & Hyposoter sp. 1 & 1 & $2 s$ & São Carlos & s VI, XII & Geometridae & Semaeopus sp. & I-XII & 240 & 1.2 \\
\hline & Hyposoter sp. 2 & 1 & 0 & & IX & Geometridae & Hymenomima conia & I, IV-X & 21 & 4.8 \\
\hline & Microcharops longiterebra & 1 & 0 & Matão & I & Limacodidae & sp. 3 & I & $1 * * *$ & - \\
\hline & Microcharops sp. & 1 & 1 & Ubatuba & III & Noctuidae & Bagisara paulensis & III & 8 & 25.0 \\
\hline Cremastinae & Eutanygaster brevipennis & 0 & 1 & Ubatuba & III & Gelechiidae & sp. 2 & III & $1 * * *$ & - \\
\hline \multirow[t]{2}{*}{ Mesochorinae } & Mesochorus sp. $1^{*}$ & 1 & $1 s$ & São Carlos & s V-VI & Tortricidae & Olethreutinae sp. & II-VIII, X & 31 & 6.5 \\
\hline & Mesochorus sp. 2** & 0 & 1 & & XII & Noctuidae & sp. 3 & XII & $1 * * *$ & - \\
\hline \multirow[t]{2}{*}{ Metopiinae } & Leurus caeruliventris & 0 & 1 & Matão & II & Gelechiidae & Dichomeris sp. & I-II, IV-VII, IX & 40 & 2.5 \\
\hline & Leurus sp. & 2 & 0 & & IV & Tortricidae & Olethreutinae sp. & I-VIII & 24 & 8.3 \\
\hline
\end{tabular}

* Reared from Hypomicrogaster sp. (Braconidae, Microgastrinae)

** Reared from Braconidae, Rogadinae (probably Aleiodes sp.)

*** The host larva was not precisely identified due to the bad condition of its remains.

Despite the representative number of samples, the caterpillars parasitized by Ichneumonidae represented only $1 \%$ of the total collected. The non-occurrence of these parasitoid species in subsequent samples may indicate that the use of the Lepidoptera species on Croton floribundus as hosts can be casual. Further studies will probably increase the amount of Ichneumonidae species associated with caterpillars feeding on C. floribundus.

Acknowledgments. To Vitor C. Becker, who identified the Gelechiidae, Pyralidae, Tortricidae and Noctuidae species, Ian D. Gauld (in memoriam) for assistance in identification of Ichneumonidae, Carolina Rodrigues de Araújo for identification of Leurus caeruliventris and the anonymous reviewers for important suggestions and comments. We also thanks the staff of the Canchim Farm (EMBRAPA/CCPSE), and that of the "Cambuhy Agrícola Ltda." Farm for permission to work in these areas, as well as the "Secretaria do Meio Ambiente" for permission to work in the "Parque Estadual da Ilha Anchieta”, and Luís A. Joaquim for the help during the collections. This study was supported by the Brazilian Government through a CNPq doctoral fellowship granted to the senior author and by the graduate program in Ecology and Natural Resources (PPG-ERN) of UFSCar.

\section{REFERENCES}

Braga, S. M. P.; M. M. Dias \& A. M. Penteado-Dias. 2001. Aspectos bionômicos de Eois tegularia (Gueneé) e Eois glauculata (Walker) (Lepidoptera, Geometridae, Larentiinae) e seus parasitóides. Revista Brasileira de Zoologia 18: 837-840.

Gauld, I. D. 1991. The Ichneumonidae of Costa Rica, 1. Memoirs of the American Entomological Institute 47: 1-589.

Gauld, I. D. 1997. The Ichneumonoidae of Costa Rica, 2. Memoirs of the American Entomological Institute 57: 1-485.

Gauld, I. D. 2000. The Ichneumonoidae of Costa Rica, 3. Memoirs of the American Entomological Institute 63: 1-453.
Gauld, I. D.; C. Godoy; R. Sithole \& J. U. Gómez. 2002. The Ichneumonidae of Costa Rica, 4. Memoirs of the American Entomological Institute 66: $1-768$.

Gupta, V. K. 1987. A revision of the genus Microcharops (Hymenoptera: lchneumonidae). Contributions of the American Entomological Institute 23: 1-42.

Hanson, P. E. \& I. D. Gauld. 1995. The Hymenoptera of Costa Rica. London, Oxford University Press, $\mathrm{xx}+893 \mathrm{p}$.

Hanson, P. E. \& I. D. Gauld. 2006. Hymenoptera de la Región Neotropical. Memoirs of the American Entomological Institute 77: 1-994.

Jerman, E. J. \& I. D. Gauld. 1988. Casinaria, a paraphyletic ichneumonid genus (Hymenoptera) and a revision of the Australian species. Journal of Natural History 22: 589-609.

Marconato, G.; M. M. Dias \& A. M. Penteado-Dias. 2008. Larvas de Geometridae (Lepidoptera) e seus parasitóides, associadas a Erythroxylum microphyllum St.- Hilaire (Erythroxylaceae). Revista Brasileira de Entomologia 52: 296-299.

Shaw, S. R. 1997. Subfamily Rogadinae, p. 403-412. In: R. A. Wharton; P. M. Marsh \& M. J. Sharkey (eds.). Manual of the New World Genera of the family Braconidae (Hymenoptera). Washington, The International Society of Hymenopterists. Special Publication 1, 439 p.

Townes, H. K. 1969. The genera of Ichneumonidae 1. Memoirs of the American Entomological Institute 11: 1-300.

Townes, H. K. 1970a. The genera of Ichneumonidae 2. Memoirs of the American Entomological Institute 12: 1-537.

Townes, H. K. 1970b. The genera of Ichneumonidae 3. Memoirs of the American Entomological Institute 13: 1-307.

Townes, H. K. 1971. The genera of Ichneumonidae 4. Memoirs of the American Entomological Institute 17: 1-372.

Townes, H. K. \& M. Townes. 1966. A catalogue and reclassification of the Neotropic Ichneumonidae. Memoirs of the American Entomological Institute 8: 1-367.

Townes, H. K. \& M. Townes. 1978. Ichneumon-flies of America North of Mexico: 7. Subfamily Banchinae, tribes Lissonotini and Banchini. Memoirs of the American Entomological Institute 26: 1-614.

Yu, D. S.; K. van Achterberg \& K. Horstmann 2005. World Ichneumonoidea. CD Rom Taxapad. 